\title{
PENGARUH GAYA KEPEMIMPINAN, BUDAYA ORGANISASI, DAN PENGEMBANGAN KARIR PADA KOMITMEN ORGANISASI DAN KINERJA
}

\author{
Sosiawan Ma'mun \\ sosiawan_mamun@yahoo.co.id \\ Sekolah Tinggi Ilmu Ekonomi (STIE) AMKOP Makassar
}

\begin{abstract}
The research aim to analysis the affects of: (1) the leadership style; (2) the organization culture; (3) the carrier development toward organization commitment and (4) the leadership style; (5) the organization culture; (6) the carrier development; (7) the organization commitment toward performance. This research applied on Regional Government Makassar City. Population all of medic employees as amount 590 persons. Sample as amount 382 respondents with analysis used Structural Equation Model with aim AMOS 18 program. The result of research found that the leadership style have positive affect and insignificant toward commitment. This mean that the application of leadership style such as forced, autocracy, affiliation, quickly, democracy and trainer cannot do implementation of work totality by employee in commitment to progress the organization. The leadership style have ngative and significant affect toward performance through commitment. This show the application of leadership style not yetable to increase the performance, because the employee have low commitment. The carrier development give dominant, positive and significant affected toward organization commitment, which mean that the employee very desire, opportunity to increase the job carrier, so get affected of work commitment.
\end{abstract}

Keywords: carrier, organization commitment and performance, culture, leadership.

\section{ABSTRAK}

Penelitian ini bertujuan untuk menganalisis pengaruh: (1) gaya kepemimpinan; (2) budaya organisasi; (3) pengembangan karirterhadap komitmen organisasi pegawai negeri sipil dan (4) gaya kepemimpinan; (5) budaya organisasi; (6) pengembangan karir; (7) komitmen organisasi terhadap kinerja pegawai negeri sipil. Penelitian dilaksanakan pada Pemerintah Kota Makassar dengan jumlah populasi pegawai berjumlah 590 orang. Sampel sebanyak 382 responden dianalisis menggunakan Structural Equation Model dengan menggunakan bantuan AMOS 18. Hasil penelitian ini ditemukan bahwa gaya kepemimpinan berpengaruh positif dan tidak signifikan terhadap komitmen organisasi. Artinya penerapan gaya kepemimpinan berupa paksaan, otokrasi, afiliasi, kecepatan, demokrasi dan pelatih tidak mampu mewujudkan totalitas kerja pegawai dalam berkomitmen organisasi memajukan organisasi. Gaya kepemimpinan berpengaruh negatif dan signifikan terhadap kinerja pegawai melalui komitmen organisasi. Ini menunjukkan penerapan gaya kepemimpinan selama ini belum mampu meningkatkan kinerja pegawai, karena pegawai juga memiliki komitmen organisasi kerja yang rendah. Pengembangan karir memberikan pengaruh dominan, positif dan signifikan terhadap komitmen organisasi, yang berarti bahwa pegawai sangat menginginkan peluang untuk meningkatkan karir kerja, sehingga memberikan pengaruh terhadap komitmen organisasi kerjanya.

Kata kunci: karir, komitmen organisasi dan kinerja, budaya, kepemimpinan.

\section{PENDAHULUAN}

Manajemen sumber daya manusia selama ini telah diterapkan, namun hasil dari penerapan tersebut belum terealisasi secara optimal sesuai yang diharapkan. Ini ter- cermin dari pencapaian kinerja pegawai yang masih rendah dalam mengembang amanah melaksanakan tugas pokok dan fungsinya dengan baik untuk mewujudkan pemerintahan yang baik (good governance). 
Amri et al. (2009: 161-186), menyatakan menilai pemerintahan tercermin dari pencapaian kinerja. Kinerja pemerintahan yang baik dihasilkan dari aparatur yang bersih dan berwibawa sesuai hasil kerja yang dicapai.

Menilai hasil kerja yang dicapai oleh aparatur Pemerintah Kota Makassar saat ini, menunjukkan hasil kerja yang belum optimal dilihat dari pencapaian realisasi dari target yang ditentukan sesuai dengan efisiensi dan efektivitas kerja berdasarkan kebijakan yang diberikan oleh pengambil keputusan dalam hal ini Bupati dan masingmasing Kepala Satuan Kerja Perangkat Daerah (SKPD). Data persentase pencapaian kinerja ini diperoleh dari data bagian pengembangan sumber daya manusia pada Bappeda Kota Makassar yang menunjukkan bahwa dalam lima tahun terakhir pencapaian kinerja mengalami penurunan dari 85.25\% tahun 2012 menurun hingga mencapai $80.79 \%$ tahun 2012 yang jauh dari pencapaian target kinerja yang diharapkan yaitu antara 90\% sampai dengan 100\%. Tentunya pencapaian kinerja dari masingmasing SKPD ada yang mencapai target $90 \%-100 \%$ tetapi lebih banyak yang tidak mencapai target yang diharapkan dari total persentase kinerja yang dicapai.

Penyebab dari pencapaian total persentase kinerja tidak tercapai sesuai realisasi dari target yang diharapkan dikarenakan hasil kerja secara kuantitas, kualitas, efisiensi, efektivitas dan kesetiaan kerja yang dimiliki pegawai rendah. Hal ini dikarenakan ada beberapa pegawai yang memiliki komitmen organisasi yang rendah. Akibat komitmen organisasi yang rendah, secara langsung atau tidak langsung dipengaruhi oleh gaya kepemimpinan yang kurang bijaksana, budaya organisasi yang kurang disikapi dan pengembangan karir yang kurang teraktualisasikan pada Pemerintah Kota Makassar.

Memahami hal tersebut, maka peneliti mempertimbangkan untuk mengkaji dan meneliti hal yang relevan dengan yang terjadi di Pemerintah Kota Makassar, dengan mencermati pengaruh gaya kepemimpinan terhadap komitmen organisasi dan kinerja pegawai. Kenyataannya terlihat bahwa diantara beberapa pimpinan SKPD di dalam mengembangkan gaya kepemim pinannya, tidak menjadikan bawahan mampu memiliki komitmen organisasi yang kuat dalam meningkatkan kinerja.

Gaya kepemimpinan yang dimiliki oleh pimpinan SKPD belum mampu mengaktualisasikan gaya kepemimpinan berupa melakukan paksaan, otokrasi, afiliasi, kecepatan, demokrasi, dan pelatih, yang menjadikan pegawai bawahannya memiliki komitmen organisasi dalam meningkatkan kinerjanya. Atas dasar itu, maka perlu pengambil keputusan organisasi untuk menerapkan teori karakteristik gaya kepemimpinan (leadership style characteristic) dari Goleman (2010: 74), gaya kepemimpinan selalu menunjukkan karakteristik mengarahkan bawahan untuk mencapai tujuan organisasi. Ada enam gaya kepemimpinan seorang pimpinan kepada bawahannya untuk mewujudkan tujuan organisasi yaitu gaya paksaan, otokrasi, afiliasi, kecepatan, demokrasi, dan pelatih. Keenam karakteristik gaya kepemimpinan ini diaktualisasikan secara konsisten, akan mempengaruhi komitmen organisasi pegawai untuk terus meningkatkan kinerjanya.

Pengaruh budaya organisasi terhadap komitmen organisasi dan kinerja pegawai Pemerintah Kota Makassar belum disikapi dengan baik oleh kebanyakan pegawai dalam menjalankan tugas pokok dan fungsinya sesuai dengan filosofi nilai budaya normatif yang telah mengakar dalam suatu organisasi. Nilai budaya organisasi yang belum teraktualisasikan dengan baik menjadikan kecenderungan pegawai memiliki integritas rendah dalam bekerja, tidak memiliki identitas kerja, kurang bertanggung jawab, kurang disiplin dan tidak berorientasi kerja sesuai dengan tuntutan yang menjadi kebiasaan dari suatu organisasi untuk maju dan berkembang.

Atas dasar budaya organisasi yang kurang disikapi oleh sebahagian pegawai di 
lingkup Pemerintah Kota Makassar, maka seyogyanya pimpinan harus mampu menyikapi pentingnya budaya organisasi untuk diterapkan dan dilaksanakan secara konsekuen dengan mengacu pada teori penilaian budaya organisasi (organization culture appraising theory) yang dikemukakan oleh Algerrow (2012: 33), bahwa budaya organisasi merupakan filosofi kebiasaan normatif yang mengakar dan menjadi penilaian dalam memajukan organisasi. Penilaian tentang budaya organisasi terdiri dari lima aspek penilaian yaitu integritas, identitas, tanggung jawab, kedisiplinan dan orientasi hasil.

Termasuk pula yang perlu dicermati dalam hal ini adalah pengaruh pengembangan karir terhadap komitmen organisasi dan kinerja pegawai. Akibat pengembangan karir yang kurang diaktualisasikan dengan baik, tidak sesuai dengan kebutuhan kerja dan pencapaian tujuan organisasi, maka di antara pegawai sering mempertanyakan wujud pengembangan karir yang harus diperoleh dalam rangka mengembangkan komitmen organisasi dan kinerjanya.

Pengembangan karir menjadi penting bagi pegawai dalam menjalankan tugas pokok dan fungsinya untuk mewujudkan kebutuhan kerja dan tujuan organisasi, hal itu yang menjadikan pegawai sering menuntut peningkatan jenjang pendidikan yang lebih tinggi, karena kenyataannya masih banyak pegawai yang berpendidikan rendah. Meminta untuk diikutkan dalam berbagi diklat yang sesuai dengan kebutuhan kerja, dikarenakan masih banyak pegawai yang belum mengikuti diklat yang berbasis kompetensi. Meminta mutasi ke unit kerja lain yang lebih baik untuk mendapatkan pengalaman dan suasana kerja yang baru, dan berupaya untuk memperoleh promosi jabatan yang lebih layak sesuai dengan karir yang ditekuni, karena biasanya promosi jabatan cenderung bersifat subyektif berdasarkan kedekatan dengan pimpinan.
Memahami pentingnya pengembangan karir terhadap komitmen organisasi kerja dan kinerja pegawai, maka perlu diterapkan teori orientasi karir dari Hasibuan (2010: 82) bahwa keberhasilan kerja pegawai tergantung pada orientasi karir. Wujud orientasi karir meliputi kemampuan bekerja berdasarkan tingkat pendidikan, pelatihan, mutasi kerja, dan promosi jabatan yang pernah dijalani dalam berkarir sesuai dengan tugas pokok dan fungsinya.

Ketiga fenomena yang dikemukakan di atas, tentunya memberikan pengaruh langsung dan tidak langsung terhadap komitmen organisasi dan kinerja pegawai. Komitmen organisasi menjadi penting untuk dipengaruhi dalam rangka meningkatkan kinerja pegawai. Komitmen organisasi yang baik tidak terlepas dari adanya pengaruh gaya kepemimpinan, budaya organisasi dan pengembangan karir.

Tentunya pihak manajemen organisasi atau pimpinan harus mampu memperbaiki komitmen organisasi dari masing-masing pegawai dalam rangka meningkatkan kinerjanya dengan menerapkan teori commitment appraising menurut Allen dan Meyer (2011: 56), bahwa komitmen organisasi dinilai berdasarkan totalitas perilaku menurut komitmen organisasi afektif, normatif, dan berkelanjutan. Wujud dari komitmen organisasi afektif yaitu berkomitmen organisasi untuk senantiasa terlibat (berpartisipasi), berkomitmen organisasi untuk mengembangkan organisasi dan berkomitmen organisasi untuk memajukan organisasi.

Ketiga wujud komitmen organisasi tersebut diharapkan pegawai dapat meningkatkan kinerjanya yang selama ini masih menunjukkan kinerja yang rendah dalam pencapaian hasil kerja. Kenyataan pegawai belum mampu mewujudkan hasil kerja yang banyak (kuantitas), menghasilkan kerja yang bermutu (kualitas), bekerja tepat waktu (efisien), bekerja berdaya guna (efektif), dan memiliki loyalitas yang tinggi terhadap pimpinan (kesetiaan). Hal inilah yang perlu menjadi pertimbangan bagi 
pimpinan untuk berupaya meningkatkan kinerjanya.

Berdasarkan uraian di atas, maka permasalahan penelitian ini adalah melihat (1) pengaruh gaya kepemimpinan, budaya organisasi, dan pengembangan karir secara langsung terhadap komitmen organisasi, (2) pengaruh gaya kepemimpinan, budaya organisasi, dan pengembangan karir secara langsung terhadap kinerja pegawai, (3) pengaruh gaya kepemimpinan, budaya organisasi dan pengembangan karir secara tidak langsung terhadap kinerja pegawai melalui komitmen organisasi, dan (4) pengaruh komitmen organisasi secara langsung terhadap kinerja pegawai.

Tujuan yang ingin dicapai dari penelitian ini adalah ingin mengetahui pengaruh langsung gaya kepemimpinan, budaya organisasi dan pengembangan karir terhadap komitmen organisasi, pengaruh langsung gaya kepemimpinan, budaya organisasi dan pengembangan karir terhadap kinerja pegawai, pengaruh tidak langsung gaya kepemimpinan, budaya organisasi dan pengembangan karir terhadap kinerja pegawai melalui komitmen organisasi, dan pengaruh tidak langsung komitmen organisasi secara langsung terhadap kinerja pegawai.

\section{TINJAUAN TEORETIS}

\section{Konsep Gaya Kepemimpinan}

Dimyanti (2012: 6-7), menguraikan beberapa teori kepemimpinan yang membicarakan mengenai bagaimana seseorang menjadi pemimpin dan bagaimana timbulnya seorang pemimpin. Teori tersebut berupa teori kelebihan, teori sifat, teori keturunan, teori kharismatik, teori bakat, dan teori sosial. Teori kelebihan beranggapan bahwa seseorang akan menjadi pemimpin apabila memiliki kelebihan daripada pengikutnya. Teori sifat menyatakan bahwa seseorang dapat menjadi pemimpin yang baik apabila memiliki sifat-sifat yang lebih daripada yang dipimpinnya. Selanjutnya teori keturunan yang menyatakan bahwa seseorang dapat menjadi pemimpin karena keturunan atau warisan. Karena orang tuanya seorang pemimpin, maka anaknya otomatis akan menjadi pemimpin menggantikan orang tuanya (Wursanto, 2012: 7). Teori kharismatik dikemukakan Wursanto (2012: 8), bahwa seorang menjadi pemimpin karena mempunyai kharisma (pengaruh) yang sangat besar. Selanjutnya teori bakat yang disebut juga teori ekologis bahwa pemimpin itu lahir karena bakatnya. Ia menjadi pemimpin karena mempunyai bakat untuk menjadi pemimpin.

Teori sosial menurut Wursanto (2012: 8) bahwa pada dasarnya setiap orang dapat menjadi pemimpin. Setiap orang mempunyai bakat untuk menjadi pemimpin asal dia diberi kesempatan. Setiap orang dapat dididik menjadi pemimpin karena masalah kepemimpinan dapat dipelajari, baik melalui pendidikan formal maupun pengalaman praktik.

Batasan kepemimpinan adalah suatu pengertian yang bersifat umum bahwa istilah ini memberikan definisi tentang makna kepemimpinan berdasarkan tinjauan gaya yang cenderung dilihat dari sosok kepemimpinan seorang pemimpin di dalam memimpin berdasarkan gaya paksaan, otokrasi, afiliasi, demokrasi, kecepatan dan pelatih. Murray (2014: 6-7), memberikan pandangan bahwa kepemimpinan merupakan gaya dalam mengembangkan motif tentang cara dalam memimpin secara memaksa (cursive style), mengembangkan otokrasi (authoritative style), sesuai tingkat kemampuan kendali bebas (affiliate style), tanpa mengabaikan metode demokrasi memimpin (demorcative style), dengan cepat melakukan tindakan (pacesetting style), dan senantiasa mendidik atau memberikan pelatihan (coaching style).

\section{Konsep Budaya Organisasi}

Menurut Robbins (2012: 14), budaya adalah seperangkat nilai-nilai yang dipelajari, diyakini, memiliki standar pengetahuan, moral, hukum, dan perilaku yang disampaikan oleh individu, organisasi atau masya- 
rakat untuk bertindak sesuai kebiasaan dasar dalam memandang dirinya.

Kostova dan Roth (2002: 215-233), menyatakan organisasi adalah sekumpulan lebih dari satu orang yang melakukan kerjasama berdasarkan kepentingan dan tujuan yang ingin dicapai. Glynn (2000: 285-298), menyatakan budaya organisasi adalah sekumpulan ideologi, simbol, dan nilai inti yang kompleks dalam mempengaruhi cara pandang organisasi.

Marcoulides dan Heck (1993: 209-255), menyatakan budaya organisasi mempunyai pengaruh yang kuat terhadap pencapaian kinerja individu dan organisasi. Realitas yang terlihat individu yang sensitif terhadap kemajuan berupaya untuk meningkatkan kemampuan kerjanya, dengan mengembangkan kebebasan kreasi kerja untuk optimalisasi kerja, individu memiliki keberanian mengembangkan peluang kerja untuk meraih prestasi kerja dan terus melakukan transparansi kerja yang lebih profesional.

\section{Konsep Pengembangan Karir}

Sumber daya manusia merupakan salah satu sumber daya yang terdapat dalam organisasi yaitu meliputi semua orang yang melakukan aktivitas. Kaplan (2001: 353-370) mengemukakan bahwa sumber daya manusia pada organisasi pemerintah adalah personalia atau aparatur atau karyawan yang bekerja di lingkungan organisasi non-profit.

Uraian di atas diketahui bahwa metode pengembangan karir harus didasarkan pada sasaran organisasi yang ingin dicapai yaitu meningkatkan pengetahuan tentang pekerjaan atau technical skill, meningkatkan kemampuan pelatihan teknis dalam mengerjakan pekerjaan atau technical skill dan melakukan mutasi dalam memberikan pengalaman dan pengembangan terhadap suatu nuansa aktivitas kerja yang lebih maju.

Jerjawi (2011), menyatakan sumber daya manusia dalam organisasi perlu di- didik, dilatih, dan dimutasi untuk mewujudkan efektivitas pengembangan karir. Secara keseluruhan dapat dipahami bahwa pengembangan karir dalam suatu organisasi pemerintahan pada dasarnya dikembangkan atas tiga fokus yaitu pendidikan, pelatihan, dan mutasi.

\section{Konsep Komitmen Organisasi}

Lazarova dan Caligiuri (2001: 389-401), mendefinisikan komitmen organisasi sebagai perwujudan totalitas kesetiaan identitas diri individu dengan organisasinya. Sementara Robbins (2012: 136), memandang komitmen organisasi sebagai suatu orientasi nilai kesetiaan secara totalitas untuk organisasi. Ibrahim (2012: 525), mengemukakan tiga karakteristik pedoman komitmen organisasi, yaitu: (1) kuatnya keyakinan mengenai organisasi, (2) mempertahankan diri agar tetap menjadi anggota organisasi, dan (3) berusaha keras sebagai bagian dari anggota organisasi.

Allen dan Meyer (2011: 18), membedakan komitmen organisasi atas tiga komponen yaitu affective commitment, normative commitment, dan continuance commitment. affective commitment adalah komitmen organisasi yang berkaitan dengan emosional, identifikasi, dan keterlibatan di dalam organisasi. Individu dengan komponen affective yang tinggi, tidak melepaskan diri dari organisasi karena keinginannya untuk tetap terikat pada organisasi. Kunci dari komitmen organisasi ini adalah employees stay because they want to. Normative commitment adalah keyakinan individu tentang kewajiban berkontribusi kepada organisasi. Individu harus melaksanakan pekerjaannya untuk mencapai tujuan yang ditetapkan organisasi. Memiliki istilah employees stay because they have to. Continuance commitment adalah suatu komitmen organisasi rasional yang terbentuk atas dasar pertimbangan untung rugi yang dihadapi individu jika berhadapan dengan keputusan untuk bergabung dalam organisasi atau hendak keluar dari organisasi (employees stay because they feel they ought to). 


\section{Konsep Kinerja}

Furtwengler (2011: 37) menjelaskan bahwa menilai kinerja individu dalam suatu organisasi wujudnya dapat dilihat dari hasil kerja yang dihasilkan secara kuantitas berupa banyaknya pekerjaan yang dihasilkan, secara kualitas mutu kerja yang dihasilkan, selalu mempertimbangkan efisiensi kerja menurut penggunaan waktu kerja dan secara efektif selalu melihat manfaat kerja yang dihasilkan serta patuh pada aturan organisasi. Kinerja sebagai kualitas dan kuantitas selalu berkaitan dengan efisiensi dan efektivitas sesuai loyalitas dalam bekerja untuk pencapaian tugas-tugas, baik yang dilakukan oleh individu, kelompok maupun organisasi (Schemerhorn et al., 2011: 91).

\section{Penelitian Terdahulu}

Penelitian Harrison (2011), dengan persamaan pada variabel bebas, variabel antara dan variabel terikat yang diteliti. Selain itu dalam menganalisis data menggunakan analisis SEM AMOS, dengan obyek penelitian pegawai pemerintah. Perbedaan terletak pada lokasi tempat penelitian. Keterbaruan penelitian ini dari penelitian terdahulu yaitu gaya kepemimpinan memberikan pengaruh positif dan tidak signifikan terhadap komitmen organisasi, dan pengaruh negatif terhadap kinerja.

Penelitian Hoggerts (2011), dengan persamaan pada variabel bebas, variabel antara dan variabel terikat yang diteliti. Selain itu dalam menganalisis data menggunakan analisis SEM AMOS. Perbedaan terletak pada obyek dan lokasi tempat penelitian. Keterbaruan penelitian ini dari penelitian terdahulu yaitu gaya kepemimpinan memberikan pengaruh positif dan tidak signifikan terhadap komitmen organisasi.

Penelitian Wijaya (2008), dengan persamaan pada variabel bebas dan variabel terikat yang diteliti. Dalam menganalisis data juga menggunakan analisis SEM AMOS. Perbedaan terletak pada obyek dan lokasi tempat penelitian. Keterbaruan penelitian ini dari penelitian terdahulu yaitu budaya organisasi memberikan pengaruh positif dan signifikan terhadap komitmen organisasi dan kinerja.

Penelitian Nurjanah (2006), dengan persamaan pada variabel bebas, variabel antara dan variabel terikat yang diteliti. Dalam menganalisis data juga menggunakan analisis SEM AMOS. Perbedaan terletak pada obyek dan lokasi tempat penelitian. Keterbaruan penelitian ini dari penelitian terdahulu yaitu gaya kepemimpinan berpengaruh positif dan tidak signifikan terhadap komitmen organisasi, sementara budaya organisasi memberikan pengaruh positif dan signifikan terhadap komitmen organisasi dan kinerja.

Penelitian Halloran (2007), dengan persamaan pada variabel bebas, variabel antara dan variabel terikat yang diteliti. Dalam menganalisis data juga menggunakan analisis SEM AMOS. Perbedaan terletak pada obyek dan lokasi tempat penelitian. Keterbaruan penelitian ini dari penelitian terdahulu yaitu gaya kepemimpinan berpengaruh positif dan tidak signifikan terhadap komitmen organisasi dan memberikan pengaruh negatif dan signifikan terhadap kinerja.

Penelitian Willy (2008), dengan persamaan pada variabel bebas, variabel antara dan variabel terikat yang diteliti. Dalam menganalisis data menggunakan analisis SEM AMOS. Perbedaan terletak pada obyek dan lokasi tempat penelitian. Keterbaruan penelitian ini dari penelitian terdahulu yaitu budaya organisasi berpengaruh positif dan signifikan terhadap kinerja.

Penelitian Halloran (2007), dengan persamaan pada variabel bebas, variabel antara dan variabel terikat yang diteliti. Dalam menganalisis data juga menggunakan analisis SEM AMOS. Perbedaan terletak pada obyek dan lokasi tempat penelitian. Keterbaruan penelitian ini dari penelitian terdahulu yaitu gaya kepemimpinan berpengaruh positif dan tidak signifikan terhadap komitmen organisasi dan memberikan pengaruh negatif dan signifikan terhadap kinerja. 
Penelitian Banamax (2011), dengan persamaan pada variabel bebas, variabel antara, dan variabel terikat yang diteliti. Dalam menganalisis data juga menggunakan analisis SEM AMOS. Perbedaan terletak pada obyek dan lokasi tempat penelitian. Keterbaruan penelitian ini dari penelitian terdahulu yaitu budaya organisasi memberikan pengaruh yang positif dan signifikan terhadap komitmen organisasi.

Penelitian Sumantoro (2010), dengan persamaan pada variabel terikat yang diteliti. Perbedaan terletak pada analisis data yang digunakan yaitu SEM AMOS pada penelitian ini dan pada penelitian Lyra dianalisis menggunakan regresi linier berganda. Perbedaan lainnya yaitu pada obyek dan lokasi tempat penelitian.

Penelitian Tysonic (2008), dengan persamaan pada variabel bebas, variabel antara, dan variabel terikat yang diteliti. Dalam menganalisis data juga menggunakan analisis SEM AMOS. Perbedaan terletak pada obyek dan lokasi tempat penelitian. Keterbaruan penelitian ini dari penelitian terdahulu yaitu gaya kepemimpinan berpengaruh positif dan tidak signifikan terhadap komitmen organisasi dan memberikan pengaruh negatif dan signifikan terhadap kinerja.

Penelitian Sabir dan Afli (2010), dengan persamaan pada variabel bebas dan variabel terikat yang diteliti. Perbedaan terletak pada alat analisis yang digunakan yaitu regresi linier berganda. Selain itu, perbedaan juga terletak pada obyek dan lokasi tempat penelitian.

Penelitian Ferdinand (2011), dengan persamaan pada variabel bebas, variabel antara dan variabel terikat yang diteliti. Dalam menganalisis data juga menggunakan analisis SEM AMOS. Perbedaan terletak pada obyek dan lokasi tempat penelitian. Keterbaruan penelitian ini dari penelitian terdahulu yaitu gaya kepemimpinan memberikan pengaruh yang tidak signifikan terhadap komitmen organisasi.

Penelitian Rahardjo dan Handayanti (2006), dengan persamaan pada variabel bebas, variabel antara dan variabel terikat yang diteliti. Dalam menganalisis data juga menggunakan analisis SEM AMOS. Perbedaan terletak pada obyek dan lokasi tempat penelitian. Keterbaruan penelitian ini dari penelitian terdahulu yaitu pengembangan karir memberikan pengaruh positif dan signifikan terhadap komitmen organisasi dan kinerja.

Penelitian Lindner (2001), dengan persamaan pada variabel bebas, variabel antara, dan variabel terikat yang diteliti. Dalam menganalisis data menggunakan analisis frekuensi dan persentase yang menjadi perbedaan dengan penelitian ini, karena penelitian ini menganalisis data menggunakan SEM AMOS. Perbedaan terletak pada obyek dan lokasi tempat penelitian. Keterbaruan penelitian ini dari penelitian terdahulu yaitu pengembangan karir memberikan pengaruh signifikan terhadap kinerja.

\section{Rerangka Pemikiran}

Konstruk variabel ini penting untuk digambarkan dalam memperlihatkan pengaruh variabel bebas yang terdiri atas gaya kepemimpinan (GKP), budaya organisasi (BOR) dan pengembangan karir (PKR) terhadap komitmen organisasi organisasi (KMT) dan kinerja (KNP). Masing-masing variabel yang ada pada rerangka konseptual ini mengacu pada teori yang mendasari. Untuk variabel gaya kepemimpinan berdasarkan teori karakteristik gaya kepemimpinan (leadership style characteristic) dari Goleman (2010: 74), yang menyatakan bahwa setiap pimpinan harus memiliki gaya kepemimpinan yang menunjukkan karakteristik mengarahkan bawahan untuk mencapai tujuan organisasi. Ada enam gaya kepemimpinan yang dapat ditunjukkan seorang pimpinan kepada bawahannya untuk mewujudkan tujuan organisasi yaitu gaya paksaan, otokrasi, afiliasi, kecepatan, demokrasi, dan pelatih.

Variabel budaya organisasi mengacu pada teori penilaian budaya organisasi (organization culture appraising theory) Algerrow (2012: 33), bahwa budaya organisasi 
merupakan filosofi kebiasaan normatif yang mengakar dan menjadi penilaian dalam memajukan organisasi. Penilaian tentang budaya organisasi terdiri dari lima aspek penilaian yaitu integritas, identitas, tanggungjawab, kedisiplinan dan orientasi hasil.

Pengembangan karir menurut teori orientasi karir dari Hasibuan (2010: 82), bahwa keberhasilan pegawai tergantung pada orientasi karir. Wujud orientasi karir meliputi kemampuan bekerja berdasarkan tingkat pendidikan, pelatihan, mutasi kerja, dan promosi jabatan. Variabel komitmen organisasi mengacu pada teori commitment appraising menurut Allen dan Meyer (2011: 56), bahwa komitmen organisasi dinilai berdasarkan totalitas perilaku menurut komitmen organisasi afektif, normatif dan berkelanjutan.

Wujud dari komitmen organisasi afektif yaitu berkomitmen organisasi untuk senantiasa terlibat (berpartisipasi), ber- komitmen organisasi untuk mengembangkan organisasi dan berkomitmen organisasi untuk memajukan organisasi.

Variabel kinerja mengacu pada teori hasil menurut Fiedler (2011: 81) bahwa penilaian kinerja berdasarkan aktivitas kerja dinilai berdasarkan asumsi kuantitas sesuai banyaknya pekerjaan yang dihasilkan, kualitas menurut mutu hasil kerja, efisiensi berdasarkan ketepatan waktu, efektivitas menurut daya guna, dan kesetiaan sesuai loyalitas terhadap pimpinan.

Pada rerangka konseptual ini juga terlihat adanya pengaruh langsung dan tidak langsung dari variabel bebas terhadap variabel antara dan variabel terikat. Pengaruh langsung yang ditunjukkan dari rerangka konseptual ini yaitu pengaruh gaya kepemimpinan, budaya organisasi dan pengembangan karir terhadap komitmen organisasi.

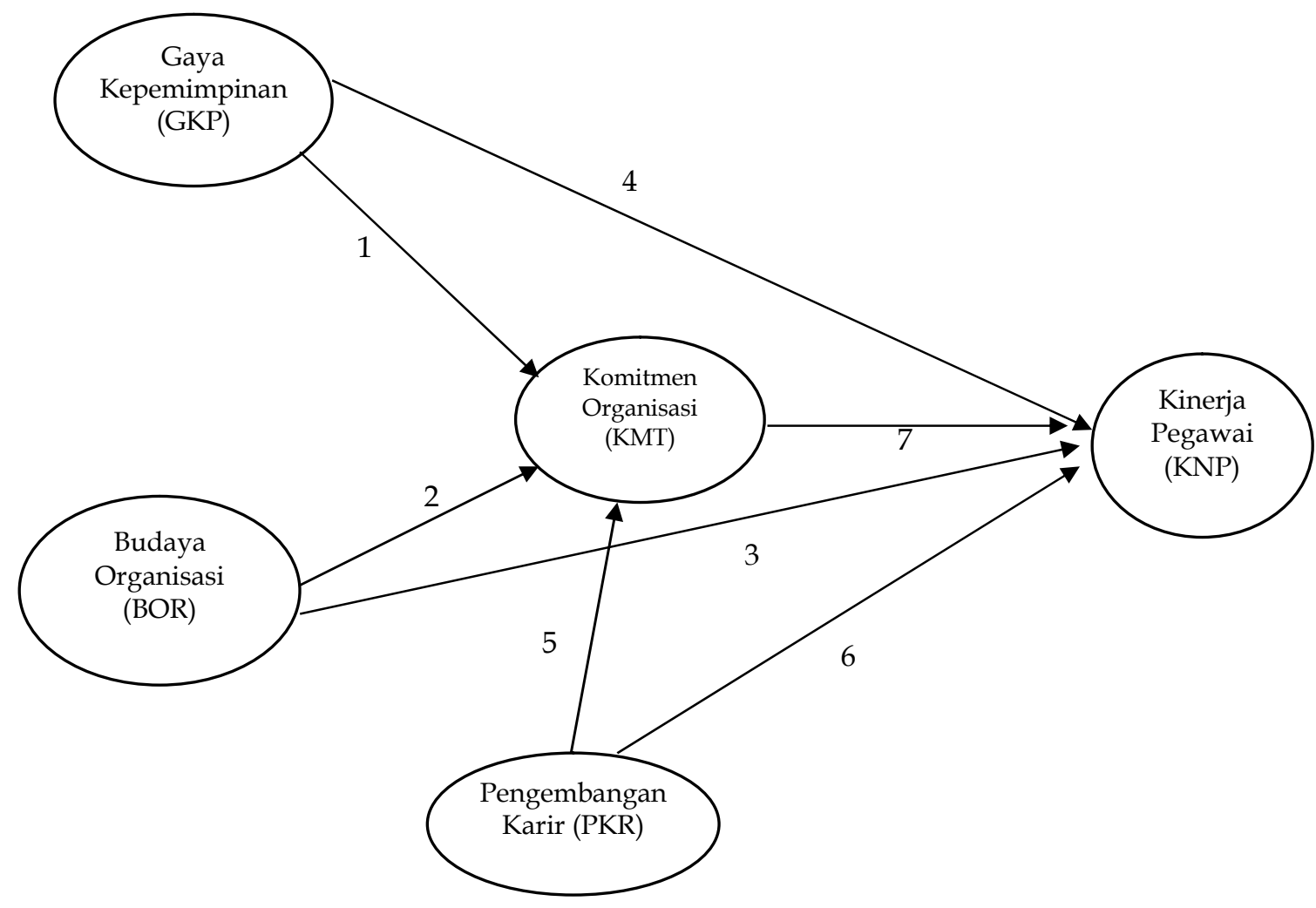

Gambar 1

Sumber: Peneliti

\section{Rerangka Konseptual}




\section{Hipotesis}

Bertitik tolak pada uraian dan rumusan masalah yang telah diuraikan di atas, maka hipotesis yang diajukan sebagai berikut:

$\mathrm{H}_{1}$ : gaya kepemimpinan berpengaruh positif dan signifikan terhadap komitmen organisasi pegawai;

$\mathrm{H}_{2}$ : budaya organisasi berpengaruh positif dan signifikan terhadap komitmen organisasi pegawai;

$\mathrm{H}_{3}$ : pengembangan karir berpengaruh positif dan signifikan terhadap komitmen organisasi pegawai;

H4: gaya kepemimpinan berpengaruh positif dan signifikan terhadap kinerja pegawai;

$\mathrm{H}_{5}$ : budaya organisasi berpengaruh positif dan signifikan terhadap kinerja pegawai;

$\mathrm{H}_{6}$ : pengembangan karir berpengaruh positif dan signifikan terhadap kinerja pegawai; dan

$\mathrm{H}_{7}$ : komitmen organisasi berpengaruh positif dan signifikan terhadap kinerja pegawai.

\section{METODE PENELITIAN}

Penelitian ini merupakan penelitian exploratory yaitu berusaha untuk mencari hubungan-hubungan yang relatif baru, dan explanatory yaitu penelitian yang dilakukan dengan cara menjelaskan gejala yang ditimbulkan oleh suatu obyek penelitian. Ditinjau dari aspek datanya penelitian ex post facto, yang berarti setelah kejadian yaitu penelitian yang bersifat pencarian empirik yang sistematik, di mana peneliti tidak dapat mengontrol variabel bebasnya karena peristiwa telah terjadi atau sifatnya tidak dapat dimanipulasi. Ditinjau dari tujuannya merupakan studi kausal yang berusaha menganalisis pengaruh gaya kepemimpinan, budaya organisasi dan pengembangan karir terhadap komitmen organisasi dan kinerja pegawai negeri sipil kota Makassar.

Teknik pengumpulan data (instrumen) yang digunakan adalah observasi, kuesioner, dan dokumentasi. Populasi dalam penelitian ini adalah seluruh pegawai negeri sipil pada Pemerintah Kota Makassar berjumlah 8.506 orang. Penelitian survei adalah penelitian yang mengambil sampel dari suatu populasi dan menggunakan kuesioner sebagai alat pengumpulan data yang pokok. Menggunakan rumus Slovin maka sampel pada penelitian ini adalah sejumlah 382 orang responden.

Variabel dalam penelitian terdiri atas variabel bebas, variabel antara, dan variabel terikat. Variabel bebas yaitu gaya kepemimpinan, budaya organisasi, dan pengembangan karir. Variabel antara yaitu komitmen organisasi dan variabel terikat yaitu kinerja pegawai. Lebih jelasnya ditunjukkan pada definisi operasional variabel beserta indikator dan pengukuran pada Tabel 1.

Teknik analisis data yang digunakan dalam menjelaskan fenomena dalam penelitian ini adalah teknik analisis statistik deskriptif dan analisis Structural Equation Modeling (SEM). Analisis statistik deskriptif digunakan untuk menjelaskan karakteristik responden meliputi jenis kelamin, pendidikan terakhir, umur, dan masa kerja. Perhitungan dalam analisis statistik deskriptif dilakukan dengan bantuan komputer menggunakan paket program AMOS 5.0 dan SPSS versi 17.0.

Structural Equation Model (SEM) adalah teknik analisis statistik inferensial yang mengkombinasikan beberapa aspek yang terdapat pada analisis jalur dan analisis faktor konfirmatori untuk mengestimasi beberapa persamaan secara simultan. Model persamaan struktural (Structural Equation Modeling) merupakan generasi kedua teknik analisis multivariate yang memungkinkan peneliti untuk menguji hubungan antara variabel yang kompleks baik recursive maupun non-recursive untuk memperoleh gambaran menyeluruh mengenai keseluruhan model.

\section{ANALISIS DAN PEMBAHASAN}

Berdasarkan cara penentuan nilai dalam model, maka variabel pengujian model pertama ini dikelompokkan menjadi varia- 
Tabel 1

Definisi Operasional Variabel Penelitian

\begin{tabular}{|c|c|c|c|}
\hline Variabel & Indikator & Skala & No. Kuesioner \\
\hline $\begin{array}{l}\text { Gaya } \\
\text { Kepemimpinan } \\
(\text { GKP) }\end{array}$ & $\begin{array}{l}\text { Paksaan } \\
\text { Otokrasi } \\
\text { Afiliasi } \\
\text { Kecepatan } \\
\text { Demokrasi } \\
\text { Pelatih } \\
\end{array}$ & $\begin{array}{c}\text { Skala Likert } \\
5,4,3,2,1\end{array}$ & $1 . \mathrm{a}-\mathrm{f}$ \\
\hline $\begin{array}{l}\text { Budaya organisasi } \\
\text { (BOR) }\end{array}$ & $\begin{array}{l}\text { Integritas } \\
\text { Identitas } \\
\text { Tanggungjawab } \\
\text { Kedisiplinan } \\
\text { Orientasi hasil }\end{array}$ & $\begin{array}{c}\text { Skala Likert } \\
5,4,3,2,1\end{array}$ & $2 . a-e$ \\
\hline $\begin{array}{l}\text { Pengembangan } \\
\text { Karir (PKR) }\end{array}$ & $\begin{array}{l}\text { Pendidikan } \\
\text { Pelatihan } \\
\text { Mutasi kerja } \\
\text { Promosi jabatan }\end{array}$ & $\begin{array}{c}\text { Skala Likert } \\
5,4,3,2,1\end{array}$ & $3 . a-d$ \\
\hline $\begin{array}{l}\text { Komitmen } \\
\text { organisasi } \\
\text { Organisasi (KMT) }\end{array}$ & $\begin{array}{l}\text { Komitmen organisasi } \\
\text { afektif } \\
\text { Komitmen organisasi } \\
\text { normatif } \\
\text { Komitmen organisasi } \\
\text { berkelanjutan }\end{array}$ & $\begin{array}{c}\text { Skala Likert } \\
5,4,3,2,1\end{array}$ & $4 . a-f$ \\
\hline $\begin{array}{l}\text { Kinerja Pegawai } \\
(\mathrm{KNP})\end{array}$ & $\begin{array}{l}\text { Kuantitas } \\
\text { Kualitas } \\
\text { Efisiensi } \\
\text { Efektivitas } \\
\text { Kesetiaan }\end{array}$ & $\begin{array}{l}\text { Skala Likert } \\
5,4,3,2,1\end{array}$ & $5 . a-e$ \\
\hline
\end{tabular}

Sumber: Peneliti

bel eksogen (exogenous variabel) dan variabel endogen (endogenous variable).

Variabel eksogen adalah variabel yang nilainya ditentukan di luar model, sedangkan variabel endogen adalah variabel yang nilainya ditentukan melalui persamaan atau dari model hubungan yang dibentuk. Termasuk dalam kelompok variabel eksogen adalah pengukuran gaya kepemimpinan, budaya organisasi dan pengembangan karir sedangkan yang tergolong variabel endogen adalah komitmen organisasi dan kinerja pegawai.

Model dikatakan baik bilamana pengembangan model hipotetik secara teoritis didukung oleh data empirik. Hasil uji mo- del dievaluasi berdasarkan goodness of fit indices pada Tabel 2 berikut dengan disajikan kriteria model serta nilai kritisnya yang memiliki kesesuaian data. Dari evaluasi model menunjukkan dari delapan kriteria goodness of fit indices terlihat hasil evaluasi kriteria goodness of fit indices tahap awal belum sesuai dengan nilai cut off yang ditentukan, sehingga dilakukan modifikasi model dengan melakukan korelasi antar error indikator sesuai dengan petunjuk dari modification indices.

Hasil uji model berdasarkan goodness of fit indices pada tabel 3 berikut dengan disajikan kriteria model serta nilai kritisnya yang memiliki kesesuaian data. 
Tabel 2

Evaluasi kriteria Goodness of Fit Indices Overall Model

\begin{tabular}{lccc}
\hline \hline \multicolumn{1}{c}{ Goodness of fit index } & Cut-off Value & Hasil Model $^{*}$ & Keterangan \\
\hline$\chi^{2}$ - Chi-square & Diharapkan kecil & 1054.732 & Marginal \\
Probability & $\geq 0,05$ & 0,000 & Marginal \\
CMIN/DF & $\leq 2,00$ & 3,650 & Marginal \\
RMSEA & $\leq 0,08$ & 0,083 & Marginal \\
GFI & $\geq 0,90$ & 0,795 & Marginal \\
AGFI & $\geq 0,90$ & 0,751 & Marginal \\
TLI & $\geq 0,94$ & 0,796 & Marginal \\
CFI & $\geq 0,94$ & 0,819 & Marginal \\
\hline
\end{tabular}

Sumber: Hair et al. (2012), Arbuckle et al. (2010)

Tabel 3

Evaluasi kriteria Goodness of Fit Indices Overall Model

\begin{tabular}{lccc}
\hline Goodness of fit index & Cut-off Value & Hasil Model $^{*}$ & Keterangan \\
\hline$\chi^{2}$ - Chi-square & $\begin{array}{c}\text { Diharapkan } \\
\text { kecil }\end{array}$ & 260.508 & Baik \\
Probability & $\geq 0,05$ & $0.05: 228=264.2242)$ & \\
CMIN/DF & $\leq 2,00$ & 1,143 & Baik \\
RMSEA & $\leq 0,08$ & 0,019 & Baik \\
GFI & $\geq 0,90$ & 0,950 & Baik \\
AGFI & $\geq 0,90$ & 0,923 & Baik \\
TLI & $\geq 0,94$ & 0,989 & Baik \\
CFI & $\geq 0,94$ & 0,992 & Baik \\
\hline
\end{tabular}

Sumber: Hair et al. (2012), Arbuckle et al. (2010)

Dari evaluasi model menunjukkan delapan kriteria goodness of fit indices telah memenuhi kriteria cut off value, sehingga model dapat dikatakan telah sesuai dengan kriteria goodness of fit indices untuk di analisis. Lebih jelasnya ditunjukkan confirmatory factor analysis untuk keseluruhan model.

Berdasarkan model empirik yang diajukan dalam penelitian ini dapat dilakukan pengujian terhadap hipotesis yang diajukan melalui pengujian koefisien jalur pada model persamaan struktural. Tabel 4 merupakan pengujian hipotesis dengan melihat nilai $p$-value, jika nilai $p$-value lebih kecil dari 0,05 maka hubungan antara variabel signifikan. Selain itu juga menjelaskan pengaruh langsung (direct effect) artinya terdapat pengaruh yang positif secara lang- sung antara variabel, pengaruh tidak langsung (indirect effect) artinya terdapat pengaruh yang positif secara tidak langsung antara variabel, dan pengaruh total (total effect) yaitu akumulasi dari pengaruh langsung dan tidak langsung. Hasil pengujian disajikan pada Tabel 4. Dari keseluruhan model enam jalur signifikan, satu jalur tidak signifikan. Adapun interpretasi dari Tabel 4 dapat dijelaskan sebagai berikut;

Pertama, gaya kepemimpinan mempunyai pengaruh positif dan tidak signifikan terhadap komitmen organisasi dengan $\mathrm{P}=0,831>0,05$ dengan nilai pengaruh langsung sebesar 0,015 yang berarti penerapan gaya kepemimpinan tidak mampu meningkatkan komitmen organisasi pegawai. 


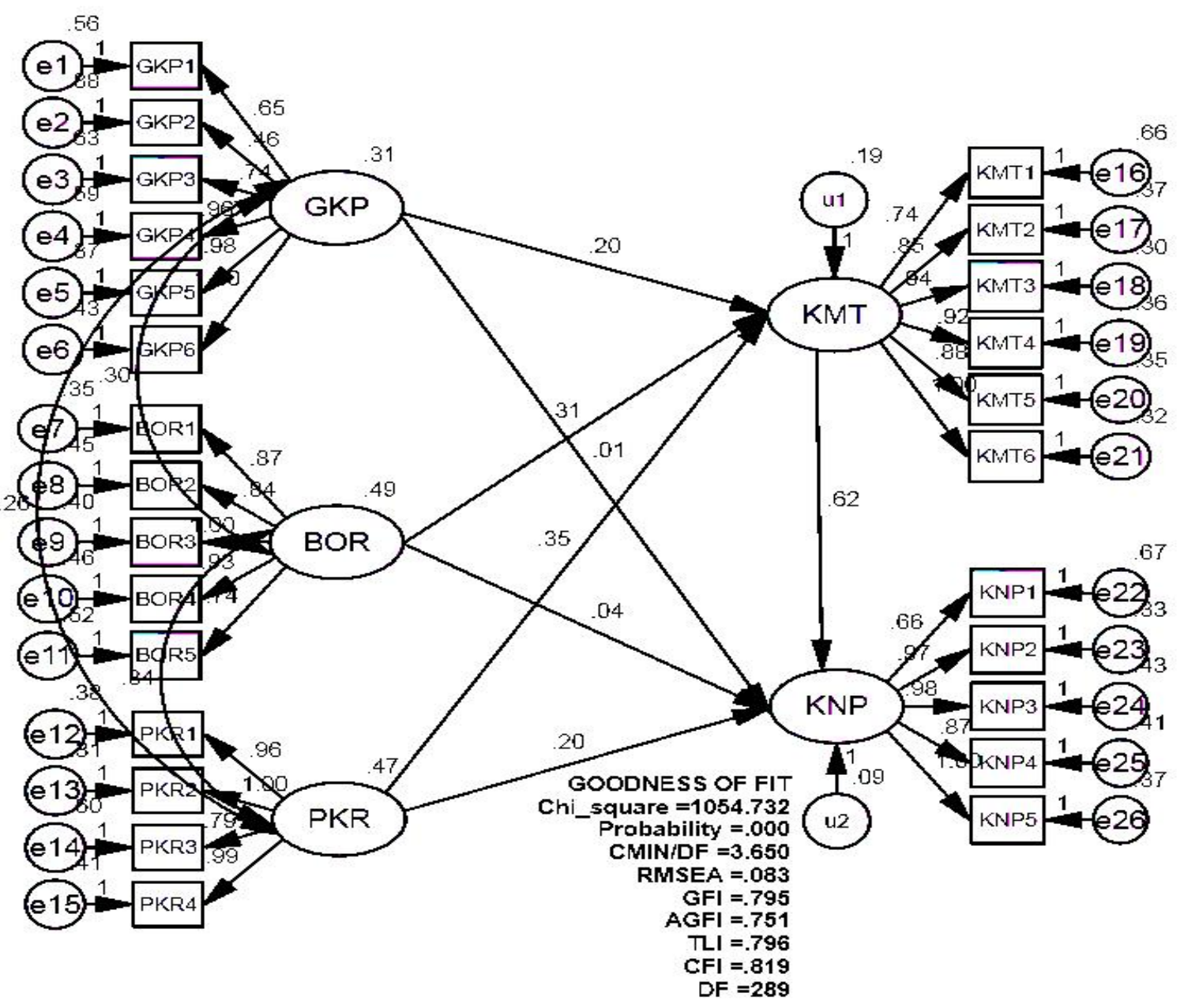

Gambar 2

Sumber: Peneliti

Confirmatory Factor Analysis untuk Keseluruhan Model

Tabel 4

Pengujian Hipotesis

\begin{tabular}{|c|c|c|c|c|c|c|c|c|c|}
\hline \multirow[b]{2}{*}{ HIP } & \multicolumn{3}{|c|}{ Variabel } & \multirow[b]{2}{*}{$\begin{array}{c}P- \\
\text { Value }\end{array}$} & \multirow[b]{2}{*}{ CR } & \multirow[b]{2}{*}{ Direct } & \multirow[b]{2}{*}{ Indirect } & \multirow[b]{2}{*}{ Total } & \multirow[b]{2}{*}{ Ket. } \\
\hline & $\begin{array}{c}\text { Variabel } \\
\text { Independen }\end{array}$ & $\begin{array}{c}\text { Variabel } \\
\text { Intervening }\end{array}$ & $\begin{array}{c}\text { Variabel } \\
\text { Dependen }\end{array}$ & & & & & & \\
\hline 1 & GKP & KMT & - & 0,831 & 0,213 & 0,015 & - & 0,015 & $\begin{array}{c}\text { Tidak } \\
\text { Signifikan }\end{array}$ \\
\hline 2 & BOR & KMT & - & 0,000 & 4,566 & 0,344 & - & 0,344 & Signifikan \\
\hline 3 & PKR & KMT & - & 0,000 & 5,882 & 0,470 & - & 0,470 & Signifikan \\
\hline 4 & GKP & KMT & KNP & 0,028 & $-2,195$ & $-0,175$ & 0,011 & $\overline{-}, 165$ & Signifikan \\
\hline 5 & BOR & KMT & KNP & 0,016 & 2,419 & 0,203 & 0,247 & 0,451 & Signifikan \\
\hline 6 & PKR & KMT & KNP & 0,039 & 2,063 & 0,185 & 0,338 & 0,523 & Signifikan \\
\hline 7 & - & KMT & KNP & 0,000 & 7,913 & 0,719 & - & 0,719 & Signifikan \\
\hline
\end{tabular}

Sumber: Data diolah (2014) 
Kedua, budaya organisasi mempunyai pengaruh positif dan signifikan terhadap komitmen organisasi dengan $\mathrm{P}=0,000<0,05$ dengan nilai pengaruh langsung sebesar 0,344 yang berarti budaya organisasi yang diterapkan pegawai sebagai wujud komitmen organisasi pegawai dalam organisasi.

Ketiga, pengembangan karir mempunyai pengaruh positif dan signifikan terhadap komitmen organisasi dengan $\mathrm{P}=0,000$ $<0,05$ dengan nilai pengaruh langsung sebesar 0,470 yang berarti pengembangan karir pegawai akan meningkatkan komitmen organisasi pegawai pada organisasi.

Keempat, gaya kepemimpinan mempunyai pengaruh negatif dan signifikan terhadap kinerja melalui komitmen organisasi dengan $\mathrm{P}=0,028<0,05$ dengan nilai pengaruh langsung sebesar $-0,175$ dan tidak langsung 0,011, yang berarti penerapan gaya kepemimpinan masih perlu ditingkatkan untuk mendukung peningkatan kinerja pegawai sesuai dengan komitmen organisasi pada organisasi. Kelima, budaya organisasi mempunyai pengaruh positif dan signifikan terhadap kinerja melalui komitmen organi sasi dengan $\mathrm{P}=0,016<0,05$ dengan nilai pengaruh langsung sebesar 0,203 dan tidak langsung 0,247, yang berarti penerapan budaya organisasi mendukung peningkatan kinerja pegawai sesuai dengan komitmen organisasi yang dimiliki.

Keenam, pengembangan karir mempunyai pengaruh positif dan signifikan terhadap kinerja melalui komitmen organisasi dengan $\mathrm{P}=0,039<0,05$ dengan nilai pengaruh langsung sebesar 0,185 dan tidak langsung 0,338 , yang berarti penerapan pengembangan karir mendukung peningkatan kinerja pegawai sesuai dengan komitmen organisasi yang dimiliki.

Ketujuh, komitmen organisasi mempunyai pengaruh positif dan signifikan terhadap kinerja dengan $\mathrm{P}=0,000<0,05$ dengan nilai pengaruh langsung sebesar 0,719 , yang berarti pegawai yang memiliki komitmen organisasi kerja memberikan pengaruh terhadap peningkatan kinerja.
Pembahasan hasil penelitian ini menjelaskan pengaruh variabel bebas terhadap variabel antara dan terikat, sesuai dengan hasil olah data analisis SEM menggunakan program AMOS untuk melihat pengaruh dan signifikansi dari masing-masing variabel yang diamati.

\section{Pengaruh Gaya Kepemimpinan terhadap Komitmen Organisasi}

Gaya kepemimpinan yang dipahami dalam penelitian ini adalah perilaku yang ditunjukkan oleh pemimpin dalam mengarahkan anggota atau bawahan dalam suatu organisasi mewujudkan pencapaian tujuan. Gaya kepemimpinan yang diterapkan di Pemerintah Kota Makassar oleh pimpinan berupa gaya paksaan, otokrasi, afiliasi, kecepatan, demokrasi, dan pelatih. Penerapan gaya kepemimpinan ini dari hasil penelitian menunjukkan secara langsung berpengaruh positif dan tidak signifikan terhadap komitmen organisasi organisasi.

Gaya kepemimpinan berpengaruh positif dilihat dari nilai direct effect yang positif dan signifikansi gaya kepemimpinan terhadap komitmen organisasi dilihat dari $p$ value di atas 0,05 yang berarti tidak signifikan. Memahami hasil penelitian ini memberikan makna bahwa gaya kepemimpinan yang diterapkan oleh pimpinan perlu untuk diperbaiki dan ditingkatkan, sehingga bawahan yang dipimpin dapat digerakkan, diarahkan dan dipengaruhi dalam menentukan komitmen organisasinya untuk menjalankan tugas pokok dan fungsi dengan baik.

Penyebab gaya kepemimpinan berpengaruh positif dan tidak signifikan terhadap komitmen organisasi dikarenakan pimpinan dalam menerapkan gaya kepemimpinan belum tegas, terlalu berkuasa, kurang sosialisasi, lambat mengambil keputusan, tidak demokrasi dan jarang memberikan pelatihan kepada bawahannya. Akibat gaya kepemimpinan tersebut menjadikan pimpinan kurang memiliki komitmen organisasi dalam menjalankan tugas pokok dan fungsinya dengan baik kepada bawahan, yang 
menyebabkan gaya kepemimpinan berpengaruh tidak signifikan terhadap komitmen organisasi.

\section{Pengaruh Budaya Organisasi terhadap Komitmen Organisasi}

Budaya organisasi yang dipahami dalam penelitian ini merupakan perwujudan dari filosofi yang menjadi kebiasaan normatif yang telah mengakar dalam suatu organisasi dan menjadi perekat organisasi menjadi maju dan berkembang. Budaya organisasi yang diterapkan pada Pemerintah Kota Makassar meliputi integritas, identitas, tangggung jawab, kedisiplinan dan orientasi hasil sebagai indikator budaya yang mempengaruhi komitmen organisasi.

Berdasarkan hasil penelitian dari olah data menunjukkan bahwa budaya organisasi berpengaruh positif dan signifikan terhadap komitmen organisasi. Pengaruh positif ini terlihat dari pengaruh langsung (direct effect) yang bernilai positif dan pengaruh signifikan atau nyata dilihat dari $p$ value $<0,05$. Hal ini bermakna bahwa penerapan budaya organisasi yang diterapkan oleh pegawai memberikan pengaruh terhadap peningkatan komitmen organisasi di dalam mewujudkan organisasi yang maju, menjalankan aktivitas kerja sesuai aturan, dan mampu mewujudkan organisasi yang berprestasi.

Penerapan budaya organisasi yang berpengaruh positif dan signifikan terhadap komitmen organisasi tidak terlepas dari besarnya kontribusi indikator nilai integritas, identitas, tanggungjawab, kedisiplinan dan orientasi hasil yang dimiliki pegawai dalam mewujudkan komitmen organisasi yang kuat. Ini berarti budaya organisasi menjadi penting dan perlu diterapkan dan disosialisasikan oleh setiap pegawai untuk senantiasa membudayakan nilai kebiasaan normatif yang telah mengakar, dipahami dan diamalkan oleh pegawai dalam melaksanakan aktivitas kerjanya untuk memiliki komitmen organisasi yang kuat.

\section{Pengaruh Pengembangan Karir terhadap Komitmen Organisasi}

Pembahasan mengenai pengembangan karir yang diamati pada penelitian ini dipahami sebagai upaya yang terorganisir dalam suatu periode waktu tertentu yang memberikan peluang kepada setiap pegawai untuk mengembangkan karirnya sesuai komitmen organisasi yang dipahaminya. Hasil penelitian pengembangan karir terhadap komitmen organisasi, berdasarkan hasil olah data menunjukkan bahwa pengembangan karir berpengaruh positif dan signifikan terhadap komitmen organisasi. Pengaruh positif tersebut dapat dilihat dari nilai direct effect yang positif dan tingkat signifikansi yang ditunjukkan $p$-value $<0,05$ yang berarti berpengaruh signifikan terhadap komitmen organisasi. Memaknai atau membahas pengembangan karir yang berpengaruh positif dan signifikan terhadap komitmen organisasi, ini tidak terlepas dari pentingnya pengembangan karir yang diterapkan oleh Pemerintah Kota Makassar. Kontribusi pengembangan karir sangat ditentukan oleh indikator latar belakang pendidikan, pelatihan yang diikuti, kebijakan mutasi yang diterapkan dan pemberian promosi sebagai penghargaan (reward) yang menyebabkan pegawai senantiasa meningkatkan komitmen organi sasinya dalam bekerja untuk memajukan, menjalankan sesuai aturan dan menjadikan organisasi berprestasi.

\section{Pengaruh Gaya Kepemimpinan terhadap Kinerja Pegawai}

Membahas pengaruh gaya kepemimpinan terhadap kinerja pegawai secara langsung memberikan pengaruh negatif dan signifikan. Ini menunjukkan bahwa gaya kepemimpinan yang diterapkan pada instansi Pemerintah Kota Makassar masih perlu ditingkatkan atau diperbaiki gaya kepemimpinan dari pemimpin untuk mengarahkan, menggerakkan dan mempengaruhi pegawai sebagai bawahannya untuk meningkatkan kinerjanya. 
Pengaruh gaya kepemimpinan yang negatif dan signifikan terhadap kinerja dapat diperbaiki atau dibenahi dengan terlebih dahulu mempengaruhi secara tidak langsung komitmen organisasi organisasi. Kenyataannya dari hasil penelitian menunjukkan bahwa pengaruh gaya kepemimpinan secara tidak langsung terhadap kinerja pegawai melalui komitmen organisasi berpengaruh positif dan signifikan.

Ini berarti gaya kepemimpinan yang diterapkan oleh pimpinan pada instansi Pemerintah Kota Makassar perlu ditingkatkan atau dibenahi dengan terlebih dahulu meningkatkan komitmen organisasi pegawai, sehingga gaya kepemimpinan ini memberikan pengaruh terhadap peningkatan kinerja pegawai.

\section{Pengaruh Budaya Organisasi terhadap Kinerja Pegawai}

Berdasarkan hasil penelitian diketahui bahwa budaya organisasi secara langsung berpengaruh positif dan signifikan terhadap kinerja. Hal ini ditunjukkan dengan direct effect yang positif dan $p$-value yang signifikan $<0,05$. Ini bermakna bahwa budaya organisasi yang diterapkan pada instansi Pemerintah Kota Makassar telah diterapkan sesuai dengan nilai integritas, identitas, tanggungjawab, kedisiplinan, dan orientasi hasil yang pengaruhnya memberikan kontribusi terhadap peningkatan kinerja pegawai.

Pengaruh budaya organisasi terhadap kinerja melalui komitmen organisasi secara tidak langsung juga berpengaruh positif dan signifikan. Hal ini terlihat pada indirect effect yang bernilai positif dengan tingkat signifikan $p$-value $<0,05$. Artinya budaya organisasi dalam penerapannya telah diterapkan pada instansi pemerintah daerah berupa nilai integritas, identitas, tanggung jawab, kedisiplinan dan orientasi hasil yang mempengaruhi peningkatan kinerja melalui penerapan komitmen organisasi baik berupa komitmen organisasi afektif, normatif dan kontinyu.
Memahami pengaruh budaya organisasi yang berpengaruh langsung dan tidak langsung terhadap kinerja pegawai melalui komitmen organisasi, memberikan pengaruh positif dan signifikan. Berarti budaya organisasi yang diterapkan selama ini memberikan pengaruh terhadap peningkatan kinerja, dan peningkatan kinerja tersebut juga tidak terlepas dari kontribusi penerapan komitmen organisasi organisasi pegawai dalam menjalankan tugas pokok dan fungsinya dengan baik.

\section{Pengaruh Pengembangan Karir terhadap Kinerja Pegawai}

Pembahasan pengaruh pengembangan karir terhadap kinerja pegawai secara langsung berdasarkan hasil penelitian memberikan pengaruh positif dan signifikan. Hal ini dapat ditunjukkan dari direct effect yang positif dengan tingkat signifikansi $p$-value $<0,05$. Pengaruh pengembangan karir secara tidak langsung terhadap kinerja melalui komitmen organisasi juga berpengaruh positif dan signifikan dilihat dari indirect effect yang positif dengan $p$-value $<0,05$ yang berarti signifikan. Ini berarti pengembangan karir menjadi hal penting bagi pegawai Pemerintah Kota Makassar dalam meningkatkan kinerjanya dan peningkatan kinerja melalui komitmen organisasi.

Pengembangan karir berpengaruh positif dan signifikan terhadap kinerja ini tidak terlepas dari besarnya kontribusi indikator pengembangan karir berupa pemberian peluang pendidikan, mengikutkan pelatihan, melakukan kebijakan mutasi, dan pemberian promosi yang diberikan pada pegawai, sehingga berpengaruh langsung terhadap peningkatan kinerja pegawai yang dapat dilihat dari peningkatan hasil kerja secara kuantitas, kualitas, efisien, efektif, dan menunjukkan sikap loyalitas. Berarti pengembangan karir menjadi hal yang berperan penting dalam mempengaruhi peningkatan kinerja pegawai.

Pengembangan karir dilihat dari pengaruh secara tidak langsung terhadap kinerja pegawai melalui komitmen organisasi 
juga berpengaruh positif dan signifikan. Berarti selain indikator pengembangan karir yang telah disebutkan di atas, indikator komitmen organisasi juga berperan penting dalam meningkatkan kinerja pegawai. Komitmen organisasi yang kuat dari pegawai tidak terlepas dari pengaruh pengembangan karir yang dimiliki pegawai dalam mempengaruhi peningkatan kinerja pegawai. Akibat pengaruh pengembangan karir melalui komitmen organisasi, kinerja pegawai meningkat di dalam mewujudkan hasil kerja yang optimal berdasarkan pencapaian secara kuantitas, kualitas, efisien, efektif dan menunjukkan sikap loyalitas.

\section{Pengaruh Komitmen Organisasi terhadap Kinerja Pegawai}

Pembahasan ini membuktikan bahwa secara langsung komitmen organisasi berpengaruh positif dan signifikan terhadap kinerja. Hal ini ditunjukkan dari nilai direct effect yang berpengaruh positif dan signifikan terhadap kinerja. Artinya, bahwa komitmen organisasi yang diterapkan pada instansi Pemerintah Kota Makassar memberikan kontribusi yang besar dalam menanamkan penguatan organisasi yang berpengaruh terhadap kinerja pegawai.

Komitmen organisasi terhadap kinerja pegawai memberikan pengaruh positif dan signifikan, tidak terlepas dari kontribusi indikator komitmen organisasi afektif (komitmen organisasi yang memajukan organisasi), komitmen organisasi normatif (komitmen organisasi mematuhi segala aturan organisasi), dan komitmen organisasi berkelanjutan (komitmen organisasi dalam mewujudkan organisasi yang berprestasi). Indikator komitmen organisasi ini menjadi penting dalam menanamkan dan memberikan pemahaman yang prinsipil di dalam mengembangkan tugas pokok dan fungsinya dalam organisasi untuk terus meningkatkan kinerjanya.

Pencapaian kinerja pegawai menjadi meningkat apabila kontribusi komitmen organisasi dijalankan dengan baik dalam mewujudkan pencapaian peningkatan ki- nerja pegawai sesuai hasil kerja secara kuantitas (jumlah pekerjaan) banyak yang dihasilkan, secara kualitas (mutu pekerjaan) yang diberikan memuaskan, efisiensi (penggunaan waktu kerja) dalam memberikan pelayanan yang tepat waktu, efektif (manfaat kerja) yang tepat guna dan loyalitas kerja (kepatuhan pada pimpinan dan aturan organisasi). Penerapan komitmen organisasi berdasarkan komitmen organisasi afektif yaitu komitmen organisasi yang dimiliki oleh pegawai untuk selalu memajukan organisasi yang berpengaruh terhadap pencapaian kinerja pegawai.

Komitmen organisasi normatif yang diterapkan oleh pegawai selama ini berupa komitmen organisasi terhadap segala aturan dan kedisplinan yang diterapkan oleh organisasi untuk dipatuhi dan ditaati dalam rangka meningkatkan kinerja organisasi. Penerapan komitmen organisasi kontinyu dalam suatu organisasi, biasanya diaktualisasikan dalam berbagai upaya untuk mewujudkan organisasi tempat kerja yang mewadahinya berprestasi sesuai dengan pencapaian kinerja yang dihasilkan.

\section{SIMPULAN DAN SARAN \\ Simpulan}

Berdasarkan analisis hasil penelitian dan pembahasan, disimpulkan bahwa gaya kepemimpinan ini dari hasil penelitian menunjukkan secara langsung berpengaruh positif dan tidak signifikan terhadap komitmen organisasi-organisasi. gaya kepemimpinan yang diterapkan oleh pimpinan perlu untuk diperbaiki dan ditingkatkan, dalam menentukan komitmen organisasinya untuk menjalankan tugas pokok dan fungsi dengan baik. Budaya organisasi berpengaruh positif dan signifikan terhadap komitmen organisasi. penerapan budaya organisasi yang diterapkan oleh pegawai memberikan pengaruh terhadap peningkatan komitmen organisasi organisasi di dalam mewujudkan organisasi yang maju, menjalankan aktivitas kerja sesuai aturan dan mampu mewujudkan organisasi yang berprestasi. 
Pengembangan karir berpengaruh positif dan signifikan terhadap komitmen organisasi. Kontribusi pengembangan karir menyebabkan pegawai senantiasa meningkatkan komitmen organisasinya dalam bekerja untuk memajukan, menjalankan sesuai aturan dan menjadikan organisasi berprestasi.

Gaya kepemimpinan terhadap kinerja pegawai secara langsung memberikan pengaruh negatif dan signifikan, dan secara tidak langsung memberikan pengaruh positif dan signifikan. Ini menunjukkan bahwa gaya kepemimpinan yang diterapkan perlu ditingkatkan atau diperbaiki untuk meningkatkan kinerjanya sesuai komitmen organisasi pegawai pada organisasi. Budaya organisasi secara langsung berpengaruh positif dan signifikan terhadap kinerja, dan budaya organisasi terhadap kinerja melalui komitmen organisasi secara tidak langsung juga berpengaruh positif dan signifikan. Artinya budaya organisasi telah diterapkan yang mempengaruhi peningkatan kinerja melalui penerapan komitmen organisasi. Pengembangan karir secara langsung dan tidak langsung berpengaruh positif dan signifikan terhadap kinerja dan melalui komitmen organisasi. Ini berarti pencapaian kinerja pegawai yang didasari oleh komitmen organisasi yang kuat berdasarkan pengembangan karir pegawai dalam organisasi. Komitmen organisasi secara langsung berpengaruh positif dan signifikan terhadap kinerja. Komitmen organisasi yang diterapkan pada instansi memberikan kontribusi yang besar dalam menanamkan penguatan organisasi yang berpengaruh terhadap kinerja pegawai.

\section{Saran}

Berdasarkan simpulan di atas, disarankan perlu perbaikan dan peningkatan penerapan gaya kepemimpinan dari setiap pegawai untuk berkomitmen organisasi dalam menjalankan tugas pokok dan fungsinya. Berupaya komitmen organisasi untuk menerapkan budaya organisasi dengan menjalankan aktivitas kerja sesuai aturan dan mampu mewujudkan organisasi yang berprestasi. Memberikan peluang kepada setiap pegawai untuk komitmen organisasi dalam mengembangkan karir guna mewujudkan organisasi yang berprestasi.

Penerapan gaya kepemimpinan untuk meningkatkan kinerja pegawai sesuai komitmen organisasi pegawai dalam memajukan organisasi. Budaya organisasi yang diterapkan harus mampu mendukung peningkatan kinerja melalui penerapan komitmen organisasi. Memberikan peluang untuk mengembangkan karir pegawai dalam rangka meningkatkan kinerja pegawai sesuai dengan komitmen organisasi yang kuat. Menanamkan penguatan komitmen organisasi dari setiap pegawai untuk mampu menunjukkan kuantitas, kualitas, efisiensi, efektivitas dan kesetiaan pegawai pada organisasi.

\section{Keterbatasan Penelitian}

Keterbatasan penelitian ini berfokus pada pegawai di lingkup Pemerintah Kota yang diambil berdasarkan penetapan rumus Slovin, di mana keseluruhannya berjumlah ada sebanyak 8.506 pegawai, namun yang menjadi responden hanya 382 orang, sehingga tidak tergeneralisasi untuk masingmasing unit kerja yang diwakili. Selain itu variabel yang diamati hanya dibatasi pada internal organisasi yaitu variabel gaya kepemimpinan, budaya organisasi, pengembangan karir, komitmen organisasi dan kinerja, yang seharusnya dapat dikembangkan pada variabel dengan kajian eksternal organisasi sumber daya manusia seperti kerjasama, pengawasan, lingkungan kerja, dan lain sebagainya. Hasil penelitian menunjukkan bahwa gaya kepemimpinan secara langsung memberikan pengaruh positif dan tidak signifikan terhadap komitmen organisasi. Hal ini dijustifikasikan sesuai kenyataan di lapangan bahwa masih banyak pimpinan SKPD kurang memahami gaya kepemimpinan yang dikehendaki bawahannya karena cenderung masih terdapat pimpinan yang bergaya otokrasi, sehingga bawahan yang dipimpin memiliki 
komitmen organisasi yang rendah untuk memajukan organisasi. Hasil penelitian juga menunjukkan bahwa pengembangan karir memberikan pengaruh dominan, positif dan signifikan terhadap komitmen organisasi, yang berarti bahwa pegawai sangat menginginkan peluang untuk meningkatkan karir kerja, sehingga memberikan pengaruh terhadap komitmen organisasi kerjanya.

\section{DAFTAR PUSTAKA}

Algerrow, M. 2012. Performance by Human Resource Management Handbook. Ohio University Press. USA.

Allen, S. dan G. Meyer. 2011. Organization Commitment in Management Perspective. Prentice Hall. New York.

Amri, A. S dan Suwondo. 2009. Pengembangan Sumberdaya Aparatur sebagai Upaya Meningkatkan Kinerja (Studi di Kantor Sekretariat Daerah Kabupaten Sumbawa). Wacana 12(3): 161-186.

Arbuckle, J. L. 2010. IBM SPSS Amos 19 User's Guide. IBM. Chicago IL.

Banamax, A. 2011. Affect of Carrier Development, Corporate Culture and Organization Commitment toward Performance. Journal of HRM 78: 211225.

Dimyati, A. 2012. Kepemimpinan Pesantren. Jurnal Islamic Review 1(1): 6-7.

Ferdinand, A. 2012. Structural Equation Modeling dalam Penelitian Manajemen. FE Universitas Diponegoro. Semarang.

Furtwengler, D. 2011. Performance. Harper T \& Row. New York.

Fiedler, G. 2012. Performance and Management. Harper T \& Row. New York.

Goleman, D. 2010. Potential Intelligence. PT Gramedia Pustaka Utama. Jakarta.

----. 2012. Working With Potential Intelligence. PT Gramedia Pustaka Utama. Jakarta.

Glynn, M. A. 2000. When Cymbals Become Symbols: Conflict Over Organizational Identity within a Symphony Orchestra. Organization Science 11(3): 285-295.
Hoggerts, M. 2011. Application of Human Resource in High Performance. Journal of Human Resource 5: 1-10.

Halloran, J. 2011. The Effect of Format Mentoring on Employee Carrier Development, Motivation, Moral toward Organizational Commitment and Job Performance. Journal of Performance 2(1): 165-177.

Hair, J. F., W. C. Black, B. J. Babin, R. E. Anderson dan R. L. Tatham. 2012. "Multivariate Data Analysis". 6 ${ }^{\text {th }}$ ed. Prentice Hall. New Jersey.

Harrison, R. 2011. Analysis of Leadership Style, Carrier Development, Motivation and Organization Culture toward Organization Commitment to Increasing the Performance of Employee in Florida Government. Journal of Management and Performance 36(5): 136-149.

Hasibuan P. M. 2010. Manajemen Sumber Daya Manusia. Rineka Cipta. Jakarta.

Ibrahim, S. 2012. Classics of Public Administration. Harcourt Brace \& Company. New York.

Kaplan, R. A. 2001. Strategic Performance Measurement and Management in Nonprofit Organizations. Nonprofit Management \& Leadership 11(3): 353370.

Kostova, T. dan K. Roth. 2002. Adoption of an Organizational Practice by Subsidiaries of Multinational Corporations: Institutional and Relational Effects. Academy of Management Journal 45(1): 215-233.

Lazarova, M dan P. Caligiuri. 2001. Retaining Repatriates: The Role of Organizational Support Practices. Journal of World Business 36(4): 389-401.

Lindner, J. R. 2010. Competency Assessment and Human Resource Management Performance of County Extension Chairs. Journal of Research Management 15(8): 182-190.

Sabir M. dan Afli. 2010. Analisis Pengaruh Komitmen Organisasi terhadap Kinerja Pegawai. Jurnal Manajemen Sumber Daya Manusia 18(2). 
Sumantoro, L. 2010. Kajian Analisis Kinerja Pelayanan Tenaga Medis terhadap Peningkatan Komitmen Organisasi Organisasi Pasien di Rumah Sakit Dharmais Jakarta. Jurnal Sumber Daya Manusia 10(8).

Marcoulides, G. A. dan R. H. Heck. 1993. Organizational Culture and Performance: Proposing and Testing a Model. Organization Science Journal 4(2): 209-225.

Jerjawi, K. A. 2011. HR Managers' Roles \& Contributions in Merger Processes. International Journal of Human Resource Studies 1(1): 1-16.

Murray, A. 2009. Leadership Styles. The Wall Street Journal Guide to Management 20(6):6-7.

Nurjanah. 2008. Pengaruh Gaya Kepemimpinan dan Budaya Organisasi terhadap Komitmen Organisasi dalam Meningkatkan Kinerja Karyawan (Studi pada Biro Lingkup Departemen Pertanian). Thesis. Program Studi Magister Manajemen Program Pasca Sarjana Universitas Diponegoro. Semarang.

Rahardjo, H. M. dan H. R. Handayani. 2006. Analisis Pengaruh Peran Kepemimpinan dan Pengembangan Karir terhadap Komitmen Organisasi dalam Meningkatkan Kinerja Karyawan (Studi
Kasus: PT. Bank Maspion Indonesia Cabang Semarang). Thesis. Program Studi Magister Manajemen Program Pasca Sarjana Universitas Diponegoro. Semarang.

Robbins, S. P. 2012. Organizational Behavior. Prentice Hall Cliffs. New Jersey.

-----. 2012. Organization Theory: Structure Designs and Applications. Prentice Hall Englewood Cliffs. New Jersey.

Schemerhorn, F., Hunt, B dan Osborn. 2011. Human Resource in Performance Management. 2nd ed. Mas Hougton Mifflin Company. Boston.

Tysonic, W. 2012. Affect Organization Commitment, Culture in Work and Leadership toward Performance and Satisfaction. Journal of Performance 18(9): 175-183.

Willy, A. 2012. Analysis of Organization Commitment, Culture and Discipline toward Morality and Performance by Lecture of San Francisco University. Journal of HRM Research 35(4): 125-136.

Wijaya, M. 2008. Pengaruh Budaya Organisasi terhadap Kinerja Karyawan di Dapur Desa Surabaya. Skripsi. Universitas Kristen Petra. Surabaya.

Wursanto. 2012. Dasar-dasar Ilmu Organisasi. Andi Yogyakarta. Yogyakarta. 